\title{
Molecular responses of Ostrea edulis haemocytes to an in vitro infection with Bonamia ostreae
}

\author{
Benjamin Morga, Isabelle Arzul*, Nicole Faury, Amélie Segarra, \\ Bruno Chollet and Tristan Renault.
}

Institut Français de Recherche pour l'Exploitation de la Mer (IFREMER); Laboratoire de Génétique et Pathologie (LGP); La Tremblade, France

\begin{abstract}
*Corresponding author. Mailing address: IFREMER, Laboratoire de Génétique et Pathologie, Avenue de Mus de Loup, 17390 La Tremblade, France. Phone: +33 5467626 10. Fax: +33 546762611 . Email: iarzul@ifremer.fr
\end{abstract}

\begin{abstract}
:
Bonamiosis due to the parasite Bonamia ostreae is a disease affecting the flat oyster Ostrea edulis. B. ostreae is a protozoan, affiliated to the order of haplosporidia and to the cercozoan phylum. This parasite is mainly intracellular, infecting haemocytes, cells notably involved in oyster defence mechanisms.

Suppression subtractive hybridisation (SSH) was carried out in order to identify oyster genes differentially expressed during an infection of haemocytes with $\mathrm{B}$. ostreae. Forward and reverse banks allowed obtaining 1104 and 1344 clones respectively, among which 391 and 480 clones showed a differential expression between both tested conditions (haemocytes alone versus haemocytes in contact with parasites). ESTs of interest including genes involved in cytoskeleton, respiratory chain, detoxification membrane receptors, and immune system were identified. The open reading frames of two selected genes (galectin and IRF-like) were completely sequenced and characterized. Real time PCR assays were developed to study the relative expression of candidate ESTs during an in vitro infection of haemocytes by live and dead parasites.

Haemocyte infection with B. ostreae induced an increased expression of omega glutathione Stransferase (OGST), superoxide dismutase (SOD), tissue inhibitor of metalloproteinase (TIMP), galectin, interferon regulatory factor (IRF-like) and filamin genes.
\end{abstract}

Keywords: Bonamia ostreae; Protozoan; Ostrea edulis; Flat oyster; Haemocytes; Gene expression; Suppression subtractive hybridisation 


\section{Introduction}

The parasite Bonamia ostreae was firstly described in France in association with mass mortality of flat oysters occurring in the late 1970's along the French coast (Pichot et al. 1979 and Comps et al. 1980). This intracellular protozoan has contributed to drastically decrease the French production of flat oysters which is now estimated at 1 900t per year (data available in the fishstat database, http://www.fao.org/fi/statist/FISOFT/FISHPLUS.asp). Bonamia ostreae is affiliated to the order of haplosporidia and to the phylum of cercozoan (Cavalier-Smith and Chao, 2003). The parasite is most often observed inside the haemocytes (Pichot et al. 1979; Comps et al. 1980), but it can also be observed extracellularly in the digestive gland and in the gills (Montes et al. 1994). The multiplication of the parasite is associated with haemocyte disruption. Haemocytic infiltration is observed in different tissues including digestive gland, mantle and gills (Balouet et al. 1983 ; Cochennec-Laureau et al. 2003).

Haemocytes, the circulating cells present in haemolymph, play a key role in the immune response of molluscs (Fisher, 1986). Bivalves lack specific immune system and immune memory. Their immune response relies on innate cellular and humoral mechanisms both operating in coordination to recognise and eliminate pathogens. Phagocytosis is the main cellular immune response against pathogens in molluscs (Cheng, 1981; Feng, 1988). Phagocytosis includes three main steps: recognition/adhesion, engulfment/internalisation and degradation (Cheng, 1981; Feng, 1988). However, after internalisation, various pathogens are able to survive in the phagocytes escaping postphagocytosis mechanisms (Alavi et al. 2009). Previous studies have shown that B. ostreae is internalised after two hours of contact. Chagot et al. (1992) and Mourton et al. (1992) have demonstrated that the parasite $B$. ostreae was internalised after 30 min of contact with haemocytes and was not degraded after phagocytosis. Few studies have investigated the immune response of bivalve molluscs against parasites using molecular techniques (Tanguy et al. 2004; Kang et al. 2006 ; Green et al. 2009 and Prado-alvarez et al. 2009). Such studies are usually based on the suppression subtractive hybridisation (SSH) technique. This approach allows the identification of genes differentially expressed between two conditions.

Studies carried out on the interactions between haemocytes and parasites have been performed by cellular approaches (Mourton et al. 1992, Xue and Renault, 2001, Cochennec-Laureau et al. 2003 and Morga et al. 2009). Molecular responses of Ostrea edulis oysters against the parasite Bonamia ostreae have never been investigated. Moreover, few sequence data on Ostrea edulis genome are available in public databases (Genbank). The only sequences available have been used to determine the phylogenetic position of Ostrea edulis (Lopez-Flores et al. 2004).

In this context, the aim of the present study was the identification of flat oyster genes differentially expressed by haemocytes infected by the parasite $B$. ostreae compared to haemocytes alone using SSH approach. Among the obtained librairies, nine ESTs were selected according to their putative biological function: (1) detoxification and stress protein (cytochrome p450, OGST, HSP 90, SOD), (2) cell communication, membrane receptor and immune system (TIMP, galectin, IRF-like, tetraspanin) and (3) cystoskeleton structure (filamin).

In addition, RT PCR assays were developed in order to estimate expression level of ESTs of interest during an in vitro infection of haemocytes with live and dead parasites. Dead parasites allowed us to test the specificity of the haemocyte response induced live parasite. Finally, the open reading frames of two selected genes related to immunity (galectin and IRF-like) were completely sequenced and characterized.

\section{Material and methods}

\subsection{Biological material}

\subsubsection{Oysters}

Two-year-old flat oysters Ostrea edulis $(n=90)$ were collected from Quiberon Bay (Southern Brittany, France), a bonamiosis endemic zone and were acclimatized in the quarantine facilities of IFREMER laboratory in La Tremblade (Charente-maritime, France) over 30 days. Flat oysters were maintained in 120 I raceways supplied with a constant flow of seawater enriched with phytoplankton (Skeletonema costatum, Isochrisis galbana, Chaetoceros gracialis and Tetraselmis succica).

\subsubsection{Haemolymph collection}


Haemolymph was withdrawn from the adductor muscle using a $1 \mathrm{~mL}$ syringe equipped with a needle $(0.40 \times 90 \mathrm{~mm})$. Haemolymph samples were filtered on a $75 \mu \mathrm{m}$ mesh to eliminate debris and maintained on ice to prevent cell aggregation. Haemolymph samples were pooled. Haemocyte counts were performed using a Malassey cell and cell concentration was adjusted at $2.10^{6}$ cells mL-1 with seawater filtered at $0.22 \mu \mathrm{m}$ (FSW).

\subsubsection{Parasites}

Bonamia ostreae was purified according to a previously published protocol (Mialhe et al. 1988). Briefly, heavily infected oysters were selected by examination of heart tissue imprints using light microscopy. After homogenization of all the organs except the adductor muscle, the parasites were concentrated by differential centrifugation on sucrose gradients and then purified by isopycnic centrifugation on a Percoll gradient. Finally, the purified parasites were suspended in FSW. Bonamia ostreae cells were then counted using a Malassez-cell and parasite concentration was adjusted at $10.10^{7}$ cells $\mathrm{mL}-1$ with FSW.

For inactivation, parasites were heated at $100^{\circ} \mathrm{C}$ for $15 \mathrm{~min}$. The efficiency of the inactivation treatment was controlled in flow cytometry using propidium iodide (Arzul et al. 2009).

\subsection{In vitro infection protocol}

A first experiment including haemocytes alone and haemocytes infected with live parasites was performed in order to construct forward and reverse SSH libraries.

The expression level of some genes identified through SSH was then evaluated during a second in vitro experiment including two conditions i.e. haemocytes in contact with live parasites and haemocytes in contact with dead parasites and a control consisting of haemocytes alone.

Whatever was the experiment, haemocytes were maintained in contact with purified parasites (live or dead) during 2 hours. For that purpose, $5 \mathrm{ml}$ of haemocyte suspension were introduced in plastic flasks and incubated at $15^{\circ} \mathrm{C}$ for two hours until the formation of a cell layer. Supernatant was then withdrawn, preserved after $0.22 \mu \mathrm{m}$ filtration and replaced by $500 \mu \mathrm{l}$ of parasite suspension. After 2 hours, supernatant previously filtered at $0.22 \mu \mathrm{m}$ to eliminate bacteria, was introduced again in flasks. After 12-hour incubation, cells were rinsed twice with phosphate buffer saline (PBS 1X) and were processed for RNA extraction using TRIZOL reagent (Invitrogen) following the manufacturer's instructions.

\subsection{Suppression subtractive hybridisation (SSH)}

Two micrograms of mRNA ( $1 \mu \mathrm{g}$ from the haemocytes exposed to the parasite and $1 \mu \mathrm{g}$ from the haemocytes alone) were used as templates for the SSH following the PCR-select CDNA subtraction kit procedure (Clontech) (Diatchenko et al., 1996). Forward subtraction was carried out using the haemocytes exposed to the parasite as the tester and the haemocytes alone as the driver. The opposite was performed for reverse subtraction. PCR products were cloned using TOPO TA Cloning Kit (Invitrogen). White colonies were screened by macro-arrays. Inserts were PCR amplified using TOPO F and R primers (Table 1 ) and one microliter of PCR product was spotted in duplicate onto nylon membrane (Roche). cDNA was digoxygenin labelled and used as probe in hybridisation experiments using the DIG-labelling and detection kit according to the manufacturer's instructions (Roche diagnostic).

\subsection{Sequencing and sequence analysis}

Clones showing a differential digoxygenin labelling intensity between infected haemocytes and haemocytes alone were selected and amplified using TempliPhi ${ }^{\mathrm{TM}}$ DNA Sequencing Template Amplification Kit (Amersham's). PCR products isolated from individual clones were sequenced in one way with TOPO $F$ with the sequencing kit $A B I$ BigDye ${ }^{\circledR}$ terminator version 3.1 using an $A B I$ PRISM ${ }^{\circledR}$ 3130 XL-Avant Genetic Analyzer, a $36 \mathrm{~cm}$ capillary array and POP 7 polymer. Chromatograms were analyzed with Chromas 231 software. Sequences were then analysed with BlastX algorithm available from the National Center for Biotechnology Information (NCBI). EST sequences were then submitted to dbEST and GenBank databases (http://www.ncbi.nlm.nih.gov/blast/). Only E values less than $10^{-4}$ were considered significant. 


\subsection{Identification and characterization of immune-related genes}

In order to obtain the complete open reading frame (ORF) of galectine, OeGal and Interferon regulatory factor like, OeIRF, RACE PCR reactions were carried out using SMART RACE cDNA Amplification Kit from Clontech according to the manufacturer's instructions. 5' and 3' primers were designed using primer 3 software (http://biotools.umassmed.edu/bioapps/primer3 www.cgi) (3'Galrace GACATCGACTGCAGCCACTAAACAG, 5'Galrace TATGGGCTGTGTCTCTCTTCTGCTC and 3'IRFrace TGGGTCCAGACACGGGTTCAATAC, 5'IRFrace CACCTTTGCTCTCACCCAGGTTTT). After ligation and cloning in TOPO Vector System (Invitrogen) and transformation in Top 10 competent bacteria (Invitrogen), several clones were sequenced using the same protocol as described before. Open reading frames were identified using ORF finder in NCBI. Complete sequences were deposited in GenBank and assigned under the accession numbers GU320697 (OeGal) and GU320698 (OelRF-like). The isoelectric point and molecular mass were calculated in http://www.expasy.ch/tools/pi tool.html.

\subsection{Phylogenic analysis of Galectin and Interferon regulatory factor like (IRF- like)}

The sequence of the complete ORF of OeGal was aligned with homologous genes available in GenBank database (Homo sapiens sapiens NM_006149.3, Bos taurus NM_001034768.1, Mus musculus NM_010706.1, Oryctolagus cuniculus NM_001082713.1, Salmo salar NM_001146582.1, Xenopus laevis NM_001085572.1, Danio rerio AY421706.1, Strongylocentrus purpuratus XM_001191059.1, Pinctada fucata FJ267519.1, Venerupis phillipinarum EU437401.1, Biomphalaria gabralata EF687664.1 and Haliotis discus hannai EF392832.1)

The sequence of the complete ORF of OeIRF-like was aligned with IRF-1, IRF-2, IRF-3 and IRF 7 genes from GenBank database (IRF-1: Homo sapiens sapiens ABH05670.1, Mus musculus P15314.1, Oncorhynchus mykiss NP001117765.1, Salmo salar AC168339.1, Sparus aurata AAY68282.1, Scophtalmus maximus AAY68279.1, Gadus marhua ACJ06730.1, Carassius auratus ABM55678.1, Danio rerio AY421706.1, Hydra magnipapillata XP002168717.1; IRF-2 : Homo sapiens sapiens NP002190.2, Mus musculus P23906.1, Oncorhynchus mykiss AAK53987.1, Salmo salar ACl33066.1, Chana argus ABK63484.1, Siniperca chuatsi ABJ09546.1; IRF-3 : Homo sapiens sapiens AAH09395.1, Mus musculus AAH50882.1, Salmo salar ACN11005.1, Danio rerio NP001137376.1 and IRF-7: Homo sapiens sapiens AA136556.1, Mus musculus NP058546.1, Salmo salar NP001130020.1, Carassius auratus AAO18646.1).

Alignments were performed using Clustal W (Thompson et al. 1997) including in MEGA 4 (Tamura et al. 2007). A phylogenetic tree based on amino acid sequences was built using the Neighbour-Joining (Saitou and Nei, 1987) algorithm with the MEGA 4 software program. Statistical confidence on the inferred phylogenic relationships was assessed by bootstrap of 1000 replicates.

\subsection{Expression analysis of the selected ESTs by quantitative real-time PCR}

Total RNA was extracted using TRIZOL reagent (Invitrogen) following the manufacturer's instructions. Briefly, cells were lysed in TRIZOL, RNA was separated from DNA and proteins using phenol chloroform. Total RNAs were precipitated using isopropanol. The RNA pellet was washed with $75 \%$ ethanol solution and finally eluted in $22 \mu \mathrm{l}$ of DEPC water. The RNA concentration was determined using a spectrophotometer at $260 \mathrm{~nm}$ and RNA quality was assessed on a $1 \%$ agarose gel. Total RNAs were treated with RQ1 RNAse-free DNAse (Promega) to remove remaining genomic DNA.

First strand cDNA was synthesized using the oligo(dT) anchor primer (5'-GAC CACGCGTATCGATGTCGACT(16)V-3') and Moloney murine leukaemia virus (M-MLV) reverse transcriptase SuperScript III First-Strand Synthesis System for RT-PCR (Invitrogen).

For each of the selected genes, forward and reverse primers were designed using primer 3 software (http://biotools.umassmed.edu/bioapps/primer3 www.cgi) (Table 1). Real-time quantitative PCR reactions were duplicated and performed in a total volume of $25 \mu \mathrm{L}$ using a Mx3000 Thermocycler sequence detector (Stratagene) in 96-microwell plates. Each well $(25 \mu \mathrm{L})$ contained $5 \mu \mathrm{L}$ of cDNA dilution (1/30), $12.5 \mu \mathrm{L}$ of Brilliant $^{\circledR}$ SYBR $^{\circledR}$ Green II PCR Master Mix (Stratagene), $2.5 \mu \mathrm{L}$ of each diluted primer $(3 \mu \mathrm{M})$ and $2.5 \mu \mathrm{L}$ of distilled water. Thermal cycling conditions were: 1 cycle of 
activation of Hot start Taq polymerase at $95{ }^{\circ} \mathrm{C}$ for $10 \mathrm{~min} ; 40$ cycles of amplification at $95^{\circ} \mathrm{C}$ for $10 \mathrm{~s}$, $60^{\circ} \mathrm{C}$ for $30 \mathrm{~s}$; and melting temperature curve analysis at $95^{\circ} \mathrm{C}$ to $60^{\circ} \mathrm{C}$ by $0.5^{\circ} \mathrm{C}$ decrease of the temperature every $10 \mathrm{~s}$. In all cases, negative controls (without cDNA) were included to rule out DNA contamination.

For each candidate gene, melting curve and gel picture were analysed in order to verify the specificity of the amplified products and that at a single PCR product was amplified. PCR efficacy (E) was calculated for each primer pair by determining the slopes of standard curves. These curves were generated using a serial dilutions analysis of plasmid containing the insert of interest. Amplification efficacies were calculated according to the following equation $E=10^{(1-\text { slope })}$ [26].

The expression of the candidate genes was normalized using the elongation factor 1 alpha (EU651798) as housekeeping gene (Morga et al. unpublished data) and haemocytes alone were used as calibrator. Samples were analysed in replicate. Primers are shown in Table 1. Fold units were calculated using the method described by (Pfall, 2001).

\section{Results}

\subsection{ESTs sequencing identification}

The SSH technique was used to identify transcripts differentially expressed between haemocytes in contact with parasites and haemocytes alone. 864 clones were sequenced and 809 sequences (93\% of the sequenced clones) were obtained and analysed (Table 2). These sequences ranging from approximately 175 to $600 \mathrm{bp}$ in length were analysed to evaluate redundancy by multiple alignments using the Lasergene software. Finally, 330 unique ESTs were identified including 56 contigs and 274 singletons. Among these, 224 ESTs showed similarities with genes available in databases with an E value $<10^{-4}$ and clustered in 8 main categories according to their putative functions predicted by NCBI using GO (Gene Ontology) (Fig. 1): (1) detoxification, (2) cell communication, membrane receptor, immune system, (3) ribosomal protein, (4) cystoskeleton structure, (5) respiratory chain, (6) cell cycle, DNA repair, protein regulation and transcription, (7) cell metabolism and (8) hypothetical protein.

\subsection{Identification and characterization of Ostrea edulis immune-related genes}

\subsubsection{Galectin (Oegal)}

Ostrea edulis cDNA galectin (Oegal) shows a 1394 nucleotide (nt) sequence. The complete sequence was deposited in GenBank and assigned under the accession number GU320697. The sequence contains a short 5'-untranslated region (1-95 nt) followed by an ORF of $1103 \mathrm{nt}$ (335 codons: 96-1103 nt) and finished by a 3'-untranslated region (1104-1394 nt) with a polyadenylation signal (AATAAA) starting $17 \mathrm{bp}$ upstream from the polyA tail (Fig. 2). No signal and extension fragment were identified, indicating that the deduced ORF corresponding to a mature protein. The complete ORF has a putative molecular mass at $36947.07 \mathrm{Da}$ and a predicted isoelectric point at 8.93. The analysis of the ORF revealed the presence of two homologous carbohydrate recognition domains (CRD), characteristic of tandem-repeat type galectin. These CRDs, CRD1 and CRD2, consist of 121 and 134 amino acids (Fig. 2) respectively.

The analysis of the CRD1 and CRD2 allowed the identification of 8 highly conserved amino acid (aa) within each CRD. These aa are known to be involved in sugar galactosyl-binding activity in invertebrate tandem-repeat type galectins (Pace et al. 2002 and Huang et al. 2007) (Fig. 2).

Phylogenic tree analysis of vertebrate and invertebrate dual-CRD or tandem-repeat type galectins grouped Oegal within the metazoan invertebrate clade and showed closest affinity to other molluscs, including pearl oyster Pinctada fucata, clam Venerupis phillipinarum, abalone Haliotis discus hannai and snail Biomphalaria gabralata (Fig. 3).

\subsubsection{Interferon regulatory factor like (OeIRF)}

Ostrea edulis cDNA interferon regulatory factor like (OeIRF) is composed of 1738 nucleotides (nt). The complete sequence was deposited in GenBank and assigned under the accession number GU320698. The sequence contains a short 5'-untranslated region (1-95 nt) followed by an ORF of $1076 \mathrm{nt}$ (326 codons: 96-1076 nt) and finished by a 3'-untranslated region (1077-1738 nt) with a polyadenylation signal (AATAAA) starting 13 bp upstream from the polyA tail (Fig. 4). No signal and extension fragment were identified, indicating that the deduced ORF corresponding to a mature 
protein. The complete ORF shows a molecular mass at 37208.09 Da and predicted isoelectric point at 5.32 .

The analysis of the ORF revealed the presence of an IRF superfamilly domain, including five conserved tryptophans in the DNA binding region (Fig. 4).

Phylogenic tree analysis showed that OeIRF is closer to IRF1 and 2 than to other IRFs (Fig. 5).

\subsection{ESTs expression patterns in haemocytes infected with live or dead Bonamia ostreae}

Relative expression of the selected ESTs (Table 3) was measured in haemocytes infected with live parasites and in haemocytes infected with dead parasites. Expression levels in both conditions were normalized using haemocyte alone.

Live parasites induced a significant increase of the expression levels of OGST (1.8), SOD (3.4), TIMP (1.9), OeGal (2.8), OeIRF (4), cytochrome oxydase III (1.7) and filamin (51) (Fig. 6). Expression levels of HSP 90 and cytochrome p450 were not significantly affected by the presence of the live parasites while tetraspanin (0.5) appeared down regulated in the same condition.

Presence of dead parasites induced a significant increase of the expression of parasite cytochrome p450 (2.1) and, OeIRF (1.7) and a down regulation of OeGal (0.3) and OGST (0.4) (Fig. 6).

\section{Discussion}

Diseases are one of the major risks affecting the mollusc production worldwide and the immune responses of bivalve hosts against pathogens are often scarcely understood. However, some studies have been carried out to better understand host/pathogen interactions at a molecular level in different bivalve species including Crassostrea gigas (Gueguen et al. 2003), Crassostrea virginica (Tanguy et al. 2004), Saccostrea glomerata (Green et al. 2009), Ruditapes phillipinarum (Kang et al. 2006), Mytilus galloprovincialis (Pallavicini et al. 2008 and Costa et al. 2009) and Ruditapes decussatus (Prado-alvarez et al. 2009).

The suppression subtractive hybridization method (SSH) is a PCR-based technique that allows the identification of genes differentially expressed in response to biotic or abiotic stimuli. This method is currently used to identify genes involved in different molecular mechanisms in a large variety of species including marine invertebrates (Brown et al. 2006 ; Gestal et al. 2007 ; Meistertzheim et al. 2007 and Wang et al. 2008).

The present work constitutes the first study on Ostrea edulis responses to the parasite Bonamia ostreae based on a molecular approach, i.e. SSH. Application of this method allowed the identification of 864 ESTs differentially expressed between haemocytes alone and haemocytes infected with $B$. ostreae. Among the ESTs presenting a significant homology in Genbank, nine ESTs were selected according to their putative biological function.

The expression pattern of these ESTs was measured and compared between haemocytes in contact with live and dead parasites in order to identify the modulation specifically induced by an in vitro infection with $B$. ostreae. Real-time PCR analyses confirmed the differential expression of seven out of the nine tested ESTs (more than one fold difference) between the two tested conditions and the normalisator of this experiment, i.e haemocytes alone.

In our study, the putative tetraspanin gene appeared down regulated in haemocytes in contact with live parasites. On the contrary, tetraspanin was found up-regulated in response to the parasite Perkinsus marinus 45 days after inoculation in C. virginica and C. gigas (Tanguy et al. 2004). Members of the tetraspanin family are involved in various biological processes such as cell adhesion, migration, cell fusion, co-stimulation, signal transduction, immune system and differentiation (Boucheix and Rubinstein, 2001; Hemler, 2005 and Levy and Shoham, 2005); however, their precise function remains unknown.

The putative TIMP gene was found significantly more expressed in haemocytes exposed to live parasites in comparison with haemocytes exposed to killed parasites. Protease inhibitors such as TIMP were found over expressed in the context of infection with Schistosoma mansoni and Vibrio splendidus (Labreuche et al. 2006 and Guillou et al. 2007). B. ostreae like other mollusc parasites may produce proteases (Faisal et al. 1999 and Ordás et al. 2001), which may contribute to modulate the immune response of the host (Hervio et al. 1991).

The over expression of O-GST and SOD genes in presence of live parasites might be related to an increase of cytotoxic components generated during an immune response as shown by (Guillou et al. 2007) in Biomphalaria gabralata. SOD is known to be involved in the oxidative stress response. 
Glutathione S-transferases play important role in the detoxification of endogenous and exogenous toxic compounds during an immune response (Brophy and Pritchard, 1992 and Brophy and Pritchard, 1994). A previous study showed a significant decrease of reactive oxygen species (ROS) production in $O$. edulis haemocytes after an in vitro infection of $O$. edulis haemocytes with live parasites versus haemocytes alone (Morga et al. 2009). These results suggest that $B$. ostreae has inhibitory effects on ROS production through the activation of genes involved in detoxification.

The putative filamin EST, a gene related to the cytoskeloton structure, was over expressed in haemocytes in contact with live parasites compared to haemocytes in contact with dead parasites. The cytoskeleton plays a central role in many cell functions such as the maintenance of cell shape, cell division, adhesion, motility, signal transduction and protein sorting. Filamins are a family of high molecular mass cytoskeletal proteins that crosslink cortical actin into a dynamic three-dimensional structure and interact with a large number of cellular proteins of great functional diversity, suggesting that they are unusually versatile signalling scaffolds (Feng and Walsh, 2004). The filamin over expression observed in haemocytes in contact with live parasites suggests an increase of cytoskeleton polymerisation which may result in an increased parasite internalisation. These results support the hypothesis expressed by Chagot et al., (1992). These authors demonstrated that $B$. ostreae was not engulfed when haemocytes were treated with cytochalasin B prior to parasite contact suggesting an active participation of host cells in the internalisation of the parasite. Similar results were reported by Gonzales et al. (2009) for Toxoplasma gondii tachyzoites and Plasmodium berghei sporozoites.

For the first time, we detected and fully characterized a member of the IRF family in a mollusc species. The IRF family includes nine members which regulate IFN- $\alpha / \beta$ production (De Maeyer and De Maeyer-Guignard, 1988). IRFs are generally associated with the immune response against viral infectious (Collet et al. 2003). However, they have functionally diverse roles in the regulation of the immune system particularly through Toll-like receptors and other pattern-recognition receptors (Honda and Taniguchi, 2006). In the present study, the putative OeIRF was over expressed in haemocytes exposed to live parasites. This over expression of OeIRF could translate a response of the flat oyster against the infection with parasite $B$. ostreae.

A member of the galectin family was also identified and fully characterized. Lectins act as pattern recognition receptors (PRRs) (Medzhitov and Janeway, 2002), a group of diverse, soluble and membrane-associated molecules such as Toll like receptors (TLRs), nucleotide-binding oligodimerization domains (NODs) and NK cell receptors. Galectins are able to bind glycans present on the surface of microorganisms and favour the entrance of the pathogens inside the cell. A wide range of galectin types was described in mammals (Cooper 2002). The galectin presently identified in $O$. edulis (OeGal) exhibits two CRDs joined by a linker peptide and appears closed to galectin 4 of mammals. A similar galectin was described in Biomphalaria gabralata (Yoshino et al. 2008) and Pinctada fucata. Recently, a four repeat CDRs galectin was identified in C. virginica (Tasumi and Vasta, 2007). These authors investigated the role of the galectin during the interactions between oyster haemocytes and the intracellular parasite $P$. marinus. C. virginica galectin bound bacteria, phytoplankton components and preferentially Perkinsus spp. trophozoites. These results suggested the direct role of the galectin in the recognition and opsonisation of potential microbial pathogens and algal food. Similar results were obtained for the tandem repeat CRDs in B. gabralata, the intermediate host of S. mansoni (Yoshino et al. 2008). In our study, OeGal expression appeared up regulated in presence of live parasites and down regulated with dead parasites. OeGal seems thus involved in the recognition of the parasite $B$. ostreae. In a previous study, phagocytosis of $B$. ostreae was not affected by the prior incubation of haemocytes with sugar (mannose, glucose, fucose, $\mathrm{N}$-acethyl glucosamine and galactosamine) while a similar parasite treatment induced a significant decrease of in vitro infection (Chagot 1989). These results suggested that haemocyte surface lectins do not play a key role in the biding of the parasite while parasite lectins are involved as receptor or ligand during the infection process. Ours results differ from the conclusion of this previous study and suggest an involvement of the haemocyte lectins in the infection with $B$. ostreae.

The present study is the first transcriptomic investigation of interactions between haemocytes from $O$. edulis and the parasite $B$. ostreae. This work has generated new data concerning the host genome and contributes to a better understanding of the relationships between host and parasite. The analysis of expression level by real time PCR has brought new insight concerning the molecular mechanisms expressed by the haemocyte in response to the parasite internalisation. OeGal seems to be involved in the recognition of $B$. ostreae by the haemocytes. In addition the parasite seems to interact with the expression of host genes related to detoxification and immune response including SOD, OGST, TIMP and IRF-like. However, these results require further investigations. 


\section{Acknowledgement}

The authors are very grateful to anonymous reviewers for revising the manuscript. The Région of Poitou Charentes supported in part this research. The authors thank Raphael Brizard for technical assistance for the maintenance of oysters in IFREMER La Tremblade quarantine facilities. 


\section{References}

Alavi M.R., Fernandez-Robledo J.A., Vasta G.R. 2009. In vitro intracellular survival of Perkinsus marinus trophozoites upon phagocytosis by oyster (Crassostrea virginica and Crassostrea ariankensis) haemocytes. J. Parasitol. 95, 900-907.

Arzul I., Gagnaire B., Bond C., Chollet B., Morga B., Ferrand S., Robert M., Renault T., 2009. Effects of temperature and salinity on the survival of Bonamia ostreae, a parasite infecting flat oysters Ostrea edulis. Dis Aquat Org. 85, 67-75.

Balouet G., Poder M., Cahour A., 1983. Haemocytic parasitosis : morphology and pathology of lesions in the french flat oyster, Ostrea edulis L. Aquaculture. 34, 1-14.

Boucheix C and Rubinstein E., 2001 Tetraspanins. Cell Mol Life Sci. 58, 1189-1205.

Brophy P.M. and Pritchard D.I., 1992. Metabolism of lipid peroxidation products by the gastrointestinal nematodes Necator americanus, Ancylostoma ceylanicum and Heligmosomoides polygyrus. Int J Parasitol. 22, 1009-1012.

Brophy P.M. and Pritchard D.I., 1994. Parasitic helminth glutathione S-transferases: an update on their potential as targets for immuno and chemotherapy. Exp Parasitol. 79, 89-96.

Brown M., Davies I.M., Moffat C.F., Craft J.A., 2006. Application of SSH and a macroarray to investigate altered gene expression in Mytilus edulis in response to exposure to benzo(a)pyrene. Mar Environ Res. 62, 128-135.

Cavalier-Smith T. and Chao E.E., 2003. Phylogeny and classification of phylum Cercozoa (Protozoa). Protist. 143, 341-358.

Chagot D., 1989. Caractérisation morphologique et fonctionnelle des hémocytes d'Ostrea edulis et de Crassostrea gigas, mollusques bivalves. Etude in vitro de leurs interactions avec le protozoaire Bonamia ostreae (Acestospora). Thèse EPHE Sciences de la vie et de la terre, Université de Montpellier. 151.

Chagot D., Boulo V., Hervio D., Mialhe E., Bachere E., Mourton C., Grizel H., 1992. Interactions between Bonamia ostreae (Protozoa: Ascetospora) and hemocytes of Ostrea edulis and Crassostrea gigas (Mollusca: Bivalvia): Entry mechanisms. J. Invertebr. Pathol. 5, 241-249.

Cheng T.C., 1981. Bivalves. In: N. A. Ratcliffe and A. F. Rowley, Editors, Invertebrate Blood Cells. Academic Press. London. 233-299.

Cochennec-Laureau N., Auffret M., Renault T., Langlade A., 2003. Changes in circulating and tissueinfiltrating hemocyte parameters of European flat oysters, Ostrea edulis, naturally infected with Bonamia ostreae. J. Invertebr. Pathol. 83, 23-30.

Collet B., Hovens G.C., Mazzoni D., Hirono I., Aoki T., Secombes C.J., 2003. Cloning and expression analysis of rainbow trout Oncorhynchus mykiss interferon regulatory factor 1 and 2 (IRF-1 and IRF-2). Dev Comp Immunol. 27, 111-126.

Comps M., Tige G., Grizel H., 1980. Etude ultrastructurale d'un protiste parasite de l'huître Ostrea edulis (L.). C. R. Acad Science Paris. 290, 383-385.

Cooper D.N.W., 2002. Galectinomics: finding themes in complexity. Biochim Biophys Acta. 1572, 209_ 231.

Costa M.M., Prado-Alvarez M., Gestal C., Li H., Roch P., Novoa B. and Figueras A., 2009. Functional and molecular immune response of Mediterranean mussel (Mytilus galloprovincialis) haemocytes against pathogenassociated molecular patterns and bacteria. Dev Comp Immunol. 26, 515-523. 
De Maeyer E. and De Maeyer-Guignard J., 1988. Interferons and other regulatory cytokines. John Wiley and sons ed, New York.

Diatchenko L., Lau Y.F., Campbell A.P., Chenchik A., Moqadam F., Huang B., Lukyanov S., Lukyanov K., Gurskaya N., Syerdlov E.D., Siebert P.D., 1996. Suppression subtractive hybridization: a method for generating differentially regulated or tissue-specific cDNA probes and libraries. Proc Natl Acad Sci U S A. 12, 6025-6030.

Faisal M., Schafhauser D.Y., Garreis K.A., Elsayed E., La Peyre J.F., 1999. Isolation and characterization of Perkinsus marinus proteases using bacitracin-sepharose affinity chromatography. Comp Biochem Physiol. 123, 417-426.

Feng, S.Y., 1988. Cellular defense mechanisms of oysters and mussels. American Fisheries Society. Special Publication. 18, 153-168.

Feng Y. and Walsh C.A., 2004. The many faces of filamin: a versatile molecular scaffold for cell motility and signalling. Nat Cell Biol. 11, 1034-1038.

Fisher S.W., 1986. Structure and functions of oyster hemocytes. In: M. Brehélin, Editor, Immunity in invertebrates. 25-35.

Gestal C., Costa M., Figueras A., Novoa B., 2007. Analysis of differentially expressed genes in response to bacterial stimulation in hemocytes of the carpet-shell clam Ruditapes decussatus: identification of new antimicrobial peptides. Gene. 406, 134-143.

Gueguen Y., Cadoret J-P., Flament D., Barreau-Roumiguière C., Girardot A.L., Garnier J., Hoareau A., Bachère E., Escoubas J-M., 2003. Immune gene discovery by expressed sequence tags generated from haemocytes of the bacteria-challenged oyster Crassostrea gigas. Gene. 303, 139-145.

Guillou F., Mitta G., Galinier R., Coustau C., 2007. Identification and expression of gene transcripts generated during an anti-parasitic response in Biomphalaria glabrata. Dev Comp Immunol. 31, 657671.

Gonzalez V., Combe A., David V., Malmquist N.A., Delorme V., Leroy C., Blazquez S., Ménard R., Tardieux I., 2009. Host cell entry by apicomplexa parasites requires actin polymerisation in the host cell. Cell Host \& Microbe. 5, 259-272.

Green T.J., Tom J., Dixon T.J., Devic E., Adlard R.D. Barnes A.C., 2009. Differential expression of genes encoding anti-oxidant enzymes in Sydney rock oysters, Saccostrea glomerata (Gould) selected for disease resistance. Fish Shellfish Immunol. 26, 799-810.

Hemler M.E., 2005. Tetraspanin functions and associated microdomains Nature Reviews Molecular Cell Biology. 6, 801-811.

Hervio D., Chagot D., Godin P., Grizel H., Mialhe E., 1991. Localization and characterization of acid phosphatase activity in Bonamia ostreae (Ascetospora), an intrahemocytic protozoan parasite of the flat oyster Ostrea edulis (Bivalvia). Dis Aquat Org. 11, 67-70.

Honda K. and Taniguchi T., 2006. IRFs: master regulators of signalling by toll-like receptors and cytosolic pattern-recognition receptors. Nat Rev Immunol. 6, 644-658.

Huang X., Tsuji N., Miyoshi T., Nakamura-Tsuruta S., Hirabayashi J., Fujisaki K., 2007. Molecular characterization and oligosaccharide-binding properties of a galectin from the argasid tick Ornithodoros moubata. Glycobiology. 27, 313-323.

Kang Y.S., Kim Y.M., Park K.I., Kim Cho S., Choi K.S., Cho M., 2006. Analysis of EST and lectin expressions in haemocytes of Manila clams (Ruditapes philippinarum) (Bivalvia: Mollusca) infected with Perkinsus olseni. Dev Comp Immunol. 30, 1119-1131. 
Labreuche Y., Lambert C., Soudant P., Boulo V., Huvet A., Nicolas J.L., 2006. Cellular and molecular hemocyte responses of the Pacific oyster, Crassostrea gigas, following bacterial infection with Vibrio aestuarianus strain 01/32. Microbes Infect. 8, 2715-2724.

Levy S. and Shoham T., 2005. The tetraspanin web modulates immune-signalling complexes. Nature Rev Immunol, 5, 136-148.

Lopez-Flores I., de la Herran R., Garrido-Ramos M.A., Boudry P., Ruiz-Rejon C., Ruiz-Rejon M., 2004. The molecular phylogeny of oysters based on a satellite DNA related to transposons. Gene. $339,181-188$.

Medzhitov R. and Janeway C.A.Jr., 2002. Decoding the patterns of self and nonself by the innate immune system. Science. 296, 298-300.

Meistertzheim A.L., Tanguy A., Moraga D., Thebault M.T., 2007. Identification of differentially expressed genes of the Pacific oyster Crassostrea gigas exposed to prolonged thermal stress. FEBS. $274,6392-6402$.

Mialhe E., Bachere E., Chagot D., Grizel H., 1988. Isolation and purification of the protozoan Bonamia ostreae (Pichot et al. 1980), a parasite affecting the flat oyster Ostrea edulis (L.). Aquaculture. 71, 293-299.

Montes J., Anadon R., Azevedo C., 1994. A possible life cycle for Bonamia ostreae on the basis of electron microscopy studies. J. Invertebr. Pathol. 63, 1-6.

Morga B., Arzul I., Chollet B., Renault T., 2009. Infection with the protozoan parasite Bonamia ostreae modifies in vitro haemocyte activities of flat oyster Ostrea edulis. Fish Shellfish Immunol. 26, 836-842.

Mourton C., Boulo V., Chagot D., Hervio D., Bachere E., Mialhe E., Grizel H., 1992. Interactions between Bonamia ostreae (Protozoa: Ascetospora) and hemocytes of Ostrea edulis and Crassostrea gigas (Mollusca: Bivalvia): in vitro system establishment. J. Invertebr Pathol. 59, 235-240.

Ordás M.C., Novoa B., Faisal M., McLaughlin S., Figueras A., 2001. Proteolytic activity of cultured Pseudoperkinsus tapetis extracellular products. Comp Biochem and Physiol B Bioche Mol Biol. 130, 199-206.

Pace K.E., Lebestky T., Hummel T., Arnoux P., Kwan K., Baum L.G., 2002. Characterization of a novel Drosophila melanogaster galectin-expression in developing immune, neural, and muscle tissues. J Biol Chem. 277, 13091-13098.

Pallavicini A., Costa M.M., Gestal C., Dreos R., Figueras A., Venier P. and Novoa B., 2008. High sequence variability of myticin transcripts in hemocytes of immune-stimulated mussels suggests ancient host-pathogen interactions. Dev Comp Immunol. 32, 213-226.

Pfall MW., 2001. A new mathematical model for relative quantificationin real-time RT-PCR. Nucleic Acid Res. 29, 2002-2007.

Pichot Y., Comps M., Tige G., Grizel H., Rabouin M.A, 1979. Research on Bonamia ostreae gen. n., sp. n., a new parasite of the flat oyster Ostrea edulis (L.). Rev. Trav. Inst. Pêches Marit. 43, 131-140.

Prado-Alvarez M., Gestal C., Novoa B., Figueras A., 2009. Differentially expressed genes of the carpet shell clam Ruditapes decussatus against Perkinsus olseni. Fish Shellfish Immunol. 26, 72-83.

Saitou N. and Nei M., 1987. The neighbor-joining method: A new method for reconstructing phylogenetic trees. Molecular Biology and Evolution. 4, 406-425.

Tamura K., Dudley J., Nei M., Kumar S., 2007. MEGA4: Molecular Evolutionary Genetics Analysis (MEGA) software version 4.0. Molecular Biology and Evolution. 24, 1596-1599. 
Tanguy A., Guo X., Ford S.E., 2004. Discovery of genes expressed in response to Perkinsus marinus challenge in Eastern (Crassostrea virginica) and Pacific (Crassostrea gigas) oysters. Gene. 338, 121131.

Tasumi S. and Vasta GR., 2007. A galectin of unique domain organization from hemocytes of the Eastern oyster (Crassostrea virginica) is a receptor for the protistan parasite Perkinsus marinus. J Immunol. 179. 3086-3098.

Thompson J.D., Gibson T.J., Plewniak F., Jeanmougin F., Higgins D.G., 1997. The Clustal X windows interface: flexible strategies for multiple sequence alignment aided by quality tools. Nucleic Acids Res. 24, 4876-4882.

Wang K.J., Ren H.L., Xu D.D., Cai L., Yang M., 2008. Identification of the up-regulated expression genes in hemocytes of variously colored abalone (Haliotis diversicolor Reeve, 1846) challenged with bacteria. Dev Comp Immunol. 32, 1326-1347.

Xue Q.G., Renault T., Chilmonczyk S., 2001. Flow cytometric assessment of haemocyte subpopulations in the European flat oyster, Ostrea edulis, haemolymph. Fish Shellfish Immunol. 11, 557567.

Yoshino T.P., Dinguirard N., Kunert J., Hokke C.H., 2008. Molecular and functional characterization of a tandem-repeat galectin from the freshwater snail Biomphalaria glabrata, intermediate host of the human blood fluke Schistosoma mansoni. Gene. 411, 46-58. 


\section{Figure captions}

Figure 1 Functional classification of the sequences identified in both libraries (ESTs). Genes were clustered into 8 categories according to their putative biological function. A=forward bank and $\mathrm{B}=$ reverse bank

Figure 2 Complete ORF nucleotide and deduced amino acid sequences of the flat oyster OeGal. ORF contains two CRD, CRD1 (galect) (96-515 nt) in red, CRD2 (galect) (675-1089 nt) in yellow. Amino acid involved in sugar galactosyl-binding activity are boxed.

Figure 3 Neighbour-joining tree showing phylogenetic analysis of galectin amino acid sequences from various species. The tree is based on 1000 bootstrap replications. The scale for branch length (0.1 substitutions/site) is shown below the tree.

Figure 4 Complete ORF nucleotide and deduced amino acid sequences of the flat oyster OeIRF. ORF contains a DNA binding domain including five conserved tryptophans (underlined in yellow) and polyadenylation signal (AATAAA) (underlined in grey).

Figure 5 Neighbour-joining tree showing phylogenetic analysis of IRF 1,2,3 and 7 amino acid sequences from various species. The tree is based on 1000 bootstrap replications. The scale for branch length ( 0.1 substitutions/site) is shown below the tree.

Figure 6 Relative expression by quantitative PCR of selected transcripts from SSH (Hsp 90, cytochrome p450, o-GST, SOD, TIMP, galectin, IRF, tetraspanin and fimanin) libraries. Expression levels were normalized to EF1- $\alpha$ and presented as relative expression to controls (mean $\pm S D, n=2$ ).

* indicates significant differences of gene expression compared to controls 


\begin{tabular}{|c|c|c|c|}
\hline Name & Oligonucleotide sequence (5'-3') & $\begin{array}{l}\text { Concentration } \\
\text { of Forward } \\
\text { primer }(\mu \mathrm{M})\end{array}$ & $\begin{array}{l}\text { Concentration } \\
\text { of Reverse } \\
\text { primer }(\mu \mathrm{M})\end{array}$ \\
\hline \multirow[t]{2}{*}{ Filamin } & Forward: TGATTTAACCGACGGGAAAG & & \\
\hline & Reverse: CTTCATCACCGGTTTGTGG & 3 & 3 \\
\hline \multirow[t]{2}{*}{ TIMP } & Forward: TTCGACGCATGTATGAAAGG & & \\
\hline & Reverse: TCTGGATTCAGGCCCCTA & 1.5 & 3 \\
\hline \multirow[t]{2}{*}{ OGST } & Forward: GGTCGTCAGGGGTCAGTTT & & \\
\hline & Reverse: GGTTCCCGTTCTTGAGCA & 3 & 3 \\
\hline \multirow[t]{2}{*}{ CYTOP450 } & Forward: GTCATCAAGCGAATGCGATA & & \\
\hline & Reverse: GGAGAGCTCССТСАTTTTCC & 3 & 3 \\
\hline \multirow[t]{2}{*}{ TETRA } & Forward: TTCCATCCATTGCTGATTTG & & \\
\hline & Reverse: AGCTGAACTCTGCCGTGAAG & 3 & 3 \\
\hline \multirow[t]{2}{*}{ Hsp90 } & Forward: TTTGTGGAACGGGTCAAAA & & \\
\hline & Reverse: AACGTCGAGCACAGTCGAG & 3 & 3 \\
\hline \multirow[t]{2}{*}{ OeGal } & Forward: TCGGAGGTCGCCCTTAAT & & \\
\hline & Reverse: TTGCCGTGAACAATCAACA & 3 & 3 \\
\hline \multirow[t]{2}{*}{ SOD } & Forward: TCGTCAATGTCAGCGTGAA & & \\
\hline & Reverse: AAATGTTGGGGCTGGTGA & 3 & 3 \\
\hline \multirow[t]{2}{*}{ OelRF } & Forward: GTGCAAGGTTTGGAGTGGTT & & \\
\hline & Reverse: GAAGAGGCTGGCATCTTTTG & 3 & 3 \\
\hline \multirow[t]{3}{*}{ ElongPCRQ5m } & Forward: & & \\
\hline & GTCGCTCACAGAAGCTGTACC & 3 & 3 \\
\hline & Reverse: CCAGGGTGGTTCAAGATGAT & & \\
\hline Topo F & GACCATGATTACGCCAAGC & & \\
\hline Topo R & CCCAGTCACGACGTTG & & \\
\hline
\end{tabular}

Table 1 Combinations of primers used in quantitative PCR assays 


\begin{tabular}{|l|l|}
\hline Total number of subtracted clones & 2448 \\
\hline Total number of clones sequenced & 864 \\
\hline Sequences analysed & 809 \\
\hline $\begin{array}{l}\text { Total number of sequences with significant } \\
\text { match }\end{array}$ & 226 \\
\hline Contigs & 330 \\
\hline Singletons & 274 \\
\hline Redundancy & $40 \%$ \\
\hline Average size number pb & 402 \\
\hline
\end{tabular}

Table 2 General characteristics of the subtracted library and cDNA sequences from Ostrea edulis haemocytes. 


\begin{tabular}{|c|c|c|c|c|}
\hline length & Putative homolog protein & Homolog species & e-value & $\begin{array}{c}\text { Genbank } \\
\text { Accession } \\
\text { number }\end{array}$ \\
\hline 361 & Cytochrome P450 & Crassostrea gigas & $1 e-23$ & ABR45717 \\
\hline 360 & $\begin{array}{l}\text { Tissue inhibitor of } \\
\text { metalloproteinase }\end{array}$ & Crassostrea gigas & $3 e-40$ & AAW52530 \\
\hline 475 & $\begin{array}{l}\text { Omega class glutathione } \\
\text { S-transferase }\end{array}$ & Crassostrea gigas & $6 e-53$ & CAD89618 \\
\hline 360 & Tetraspanin & $\begin{array}{c}\text { Strongylocentrotus } \\
\text { purpuratus }\end{array}$ & $1 e-5$ & ABE27957 \\
\hline $\begin{array}{l}614 \\
359\end{array}$ & $\begin{array}{c}\text { Interferon regulatory factor } \\
\text { Heat shock protein } 90\end{array}$ & $\begin{array}{c}\text { Paralichthys olivaceus } \\
\text { Crassostrea gigas }\end{array}$ & $\begin{array}{l}2 e-22 \\
2 e-33\end{array}$ & $\begin{array}{l}\text { BAA83468 } \\
\text { ABS18268 }\end{array}$ \\
\hline 376 & $\begin{array}{l}\text { Galectin 4-like protein } \\
\text { transcript variant }\end{array}$ & Haliotis discus hannai & $1 e-21$ & ABN54798 \\
\hline 324 & $\begin{array}{l}\text { Cu/Zn superoxide } \\
\text { dismutase }\end{array}$ & $\begin{array}{l}\text { 6.1.1. Crassostrea } \\
\underline{\text { ariakensis }}\end{array}$ & $2 e-54$ & ABF14366 \\
\hline 299 & Filamin & Hirudo medicinalis & $4 \mathrm{e}-20$ & AAR36862 \\
\hline
\end{tabular}

Table 3 Candidate ESTs selected for expression level analysis by quantitative real time PCR 
Fig.1

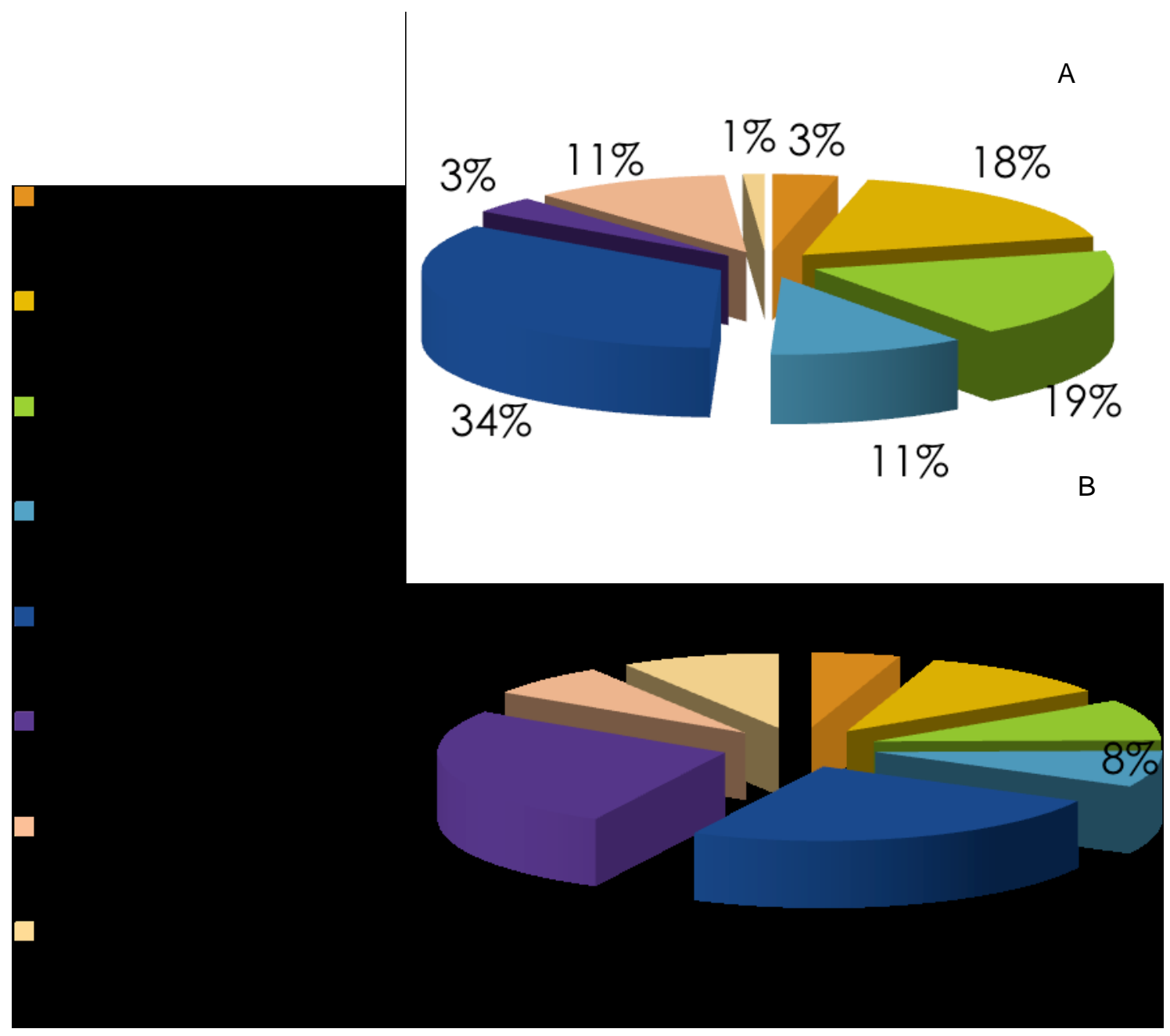

Figure 1 Functional classification of the sequences identified in both libraries (ESTs). Genes were clustered into 8 categories according to their putative biological function. $A=$ forward bank and $\mathrm{B}=$ reverse bank 
Fig.2

TCGGGGATAAGTTGGAGTGTGTGAATATTTGATAAATACCTG

CAACACAGAGCGCAGCCCTCATTTCCTTCTTCGCTGTGAAGTGAAACT

93 ATC ATG GCT ACT ATA ATG AGC CCA GGC ATT CCC TAC GTG GGA GGA

$M \quad A \quad T \quad I \quad M \quad S \quad P \quad G \quad I$ P Y V G G

138 ATC CCC GGG GGT ATG AGA GAC GGA CGC CAA ATC GTC ATC AAC GGA

$\begin{array}{lllllllllllllll}45 & I & P & G & G & M & R & D & G & R & Q & I & V & I & N\end{array}$

183 ATG GTG CCC CAC CAC GAG CAC AGT TTT TCG ATC AAC CTC CAA GCC

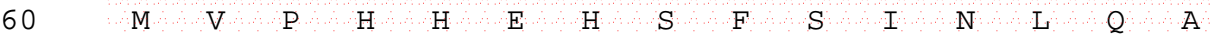

228 GGA CCA AAC ATT AAC CCT CGG TCC AAC ACA GCT CTA CAT TTC AAC

$\begin{array}{lllllllllllllllll}75 & G & P & N & I & N & P & R & S & N & T & A & L & H & F & N\end{array}$

273 CCT CGC CCG AAC GAC AAC TGT GTG GTC CGT AAT AGC TAC CAG CAC $90 \quad \mathrm{P} \quad \mathrm{R} / \mathrm{P} \quad \mathrm{N} \quad \mathrm{D} \quad \mathrm{N} \quad \mathrm{C} \quad \mathrm{V} / \mathrm{V} / \mathrm{R} / \mathrm{N} / \mathrm{S} \quad \mathrm{Y} \quad \mathrm{Q} \quad \mathrm{H}$

318

CAC AGC TGG GGA GGG GAA GAG CGA GGA GGG TAC ATG CCG TTC CAG

AGG GGA ATG CCT TTC GAA ATA ACT GTA CTC TGC CAA CAC CAC CAT

TAT AAG GTA TCA GTG AAT GGC AGA CAT TTC TGC GAT TTT CGC CAT

AGA ATC GAG AAA CAT CAC GTG AAC ACG TTG ACG ATT GAG GGC GGA

GTA CAG ATC AGC AGT ATT CGA TTC GAT GGA GCT CAA GGT CAC GGA

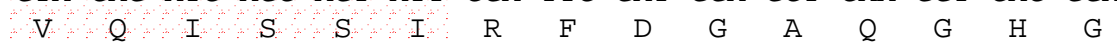

CAG GGC GTA GGG GGC TTT CCT GGT CGA GTT GTT GGA GAG ATG ACG

AAG GCT GCC ATG CCC ACA CCA TCT CCA CCA GCT GGG GCC TAC CCT

CCG GCC GGG GGG TAC CCA GGA GGG GGA GCC CAA CCC ATG TAT AAT

CCC CCG ATG CCA TTT ACC ACG CCC ATT TCT GGA GGA ATT TTT CCA

GGG AAA ATG ATT TTC ATC AGT GGA GTC CCA AAT CCG AAT GCA GAA

AGG TTC ACG TTG AAC CTA ATG TGT GGT CCC TAC GAC GGA AGT GAC

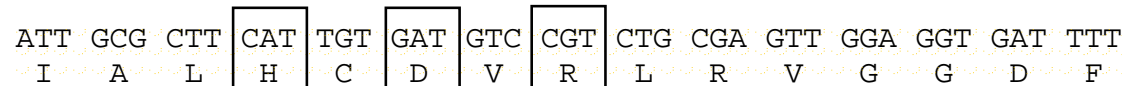

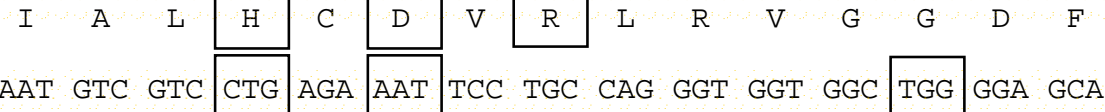
$\begin{array}{lllllllllllllllll}\mathrm{N} & \mathrm{V} & \mathrm{V} & \mathrm{L} & \mathrm{R} & \mathrm{N} & \mathrm{S} & \mathrm{C} & \mathrm{Q} & \mathrm{G} & \mathrm{G} & \mathrm{G} & \mathrm{W} & \mathrm{G} & \mathrm{A}\end{array}$

GAA GAG AGA CAC AGC CCA TAC TTT CCT TTC ATG CCA AAT GCC AAT

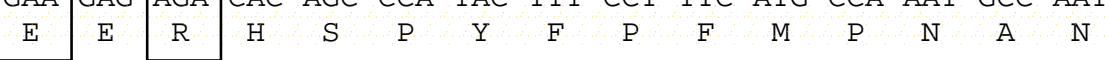

TTT GAC ATG ATT ATC ATG GCA GAA CAT GAC AAA TTC AAG ATT GCC

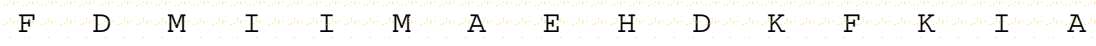

GTG AAC AAT CAA CAC TTG CTC GAG TTT AGA CAT CGA CTG CAG CCA 330 
1038 CTA AAC AGA ATC GAC ACT CTA CAG ATT AAG GGC GAC CTC CGA CTG

$\begin{array}{lllllllllllllllll}345 & \mathrm{~L} & \mathrm{~N} & \mathrm{R} & \mathrm{I} & \mathrm{D} & \mathrm{T} & \mathrm{L} & \mathrm{Q} & \mathrm{I} & \mathrm{K} & \mathrm{G} & \mathrm{D} & \mathrm{L} & \mathrm{R} & \mathrm{L}\end{array}$

1083 ACT CAA GTC CGA TTC CAA TAA ATT TAT ATG TCA TTA TCA TCA TAC

$\begin{array}{llllllll}360 & T & Q & V & R & F & Q\end{array}$

1128 ATTCATACAAGAAACAAAATGCAGAGCAAATAATTGGTTAAAGTA

1173 TTGTACATTTGTATTTTTGTTGAAACAAATGATTATTTAATCTCT

1218 CTCTTTCACTCATATCAACATATGATATGGTACTTTCCTGCTATT

1263 TCAATACGATTATACAAATATCACTGGATAACCCAGGCAATAAAA

1308 ACACTAAGTGTATTTTAAAAAAAAAAAAAAAAAAAAAAAAAA

Figure 2 Complete ORF nucleotide and deduced amino acid sequences of the flat oyster OeGal. ORF contains two CRD, CRD1 (galect) (96-515 nt) in red, CRD2 (galect) (675-1089 nt) in yellow. Amino acid involved in sugar galactosyl-binding activity are boxed. 
Fig.3

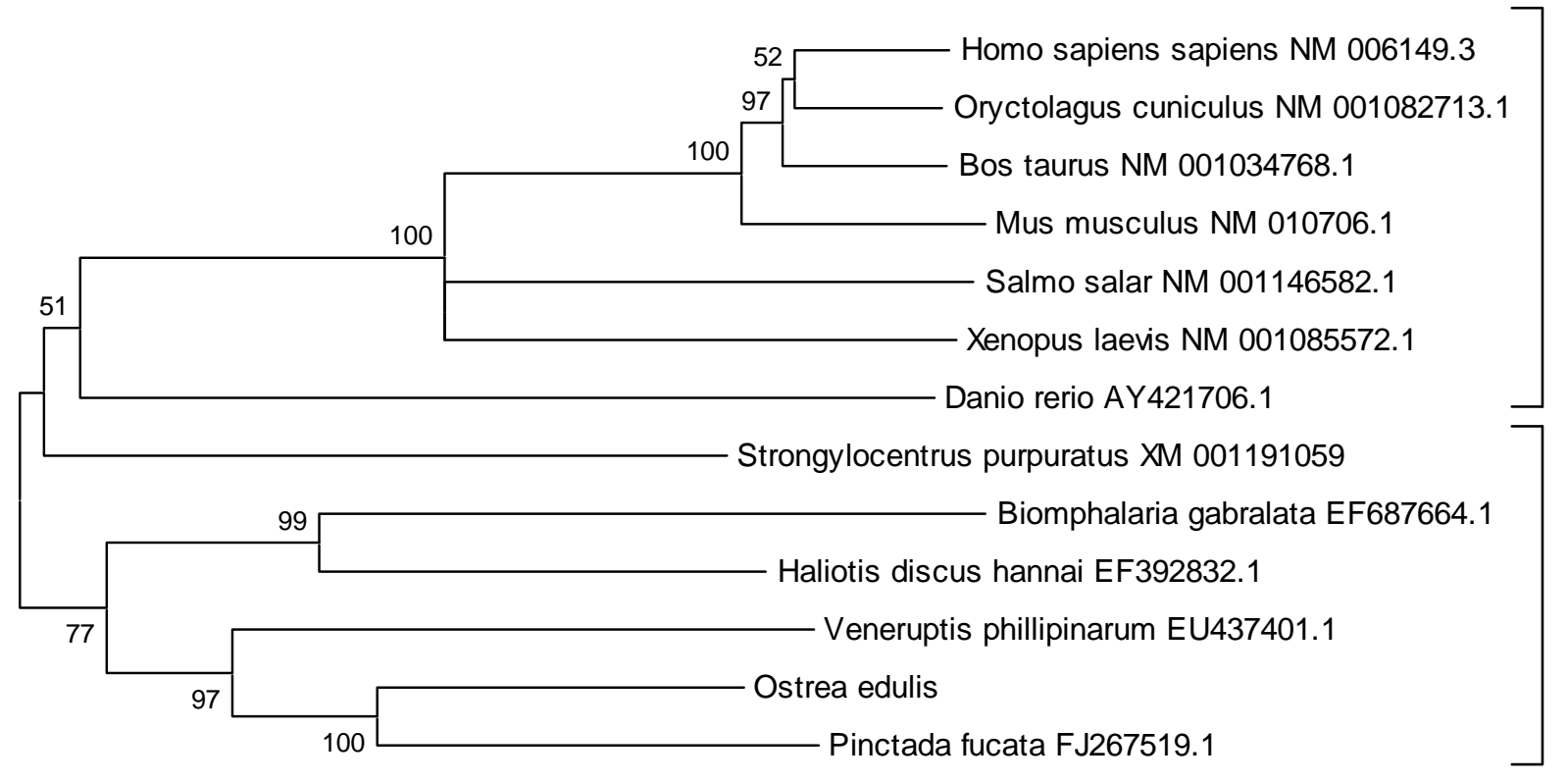

Vertebrates

Invertebrates

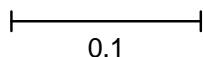

Figure 3 Neighbour-joining tree showing phylogenetic analysis of galectin amino acid sequences from various species. The tree is based on 1000 bootstrap replications. The scale for branch length $(0.1$ substitutions/site) is shown below the tree. 
Fig.4

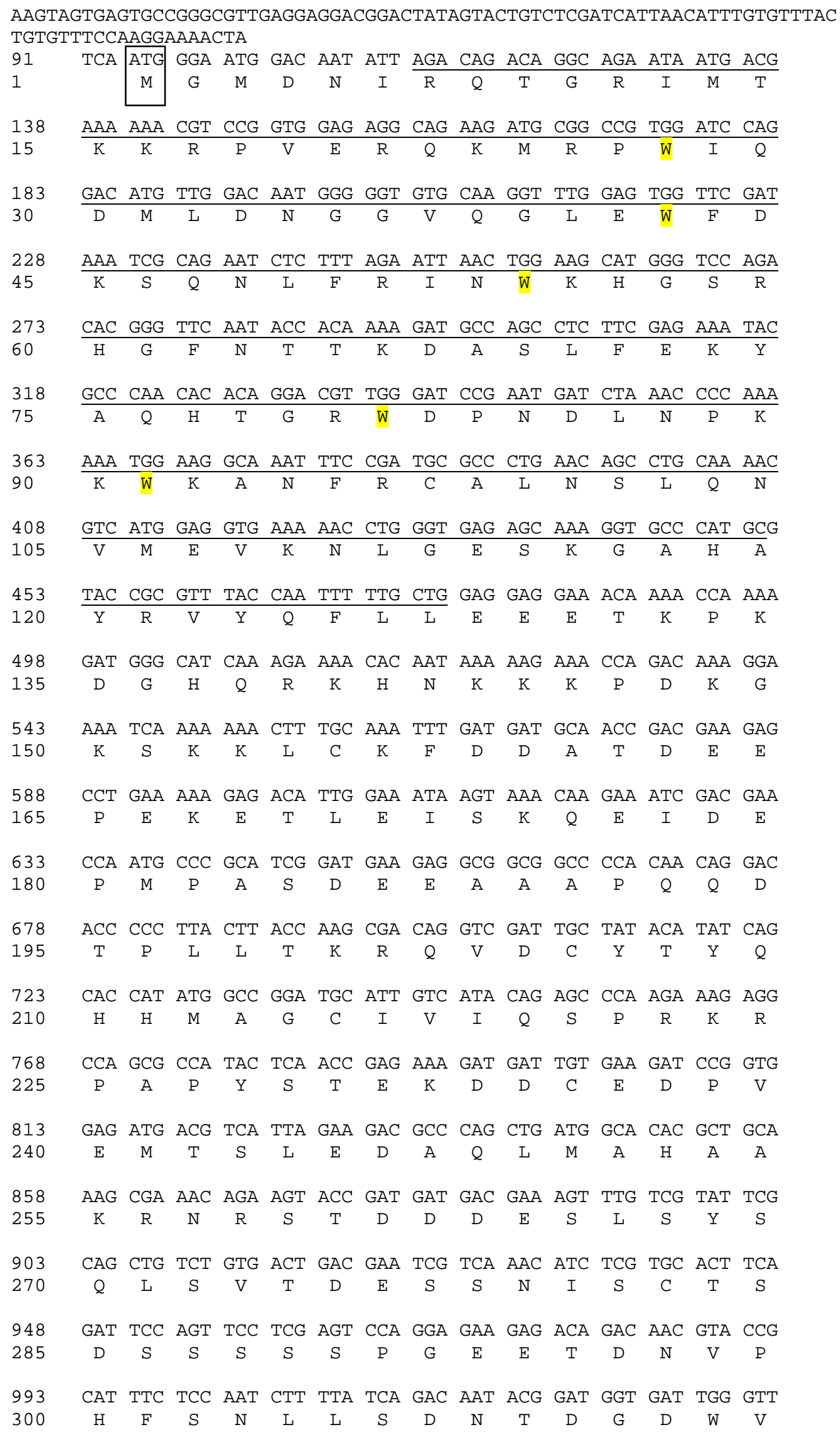


1038 ATT GAA AGC GAG GAA ACT GTA ACT ACA ACC GAC TCC TGA ACG AAC

$\begin{array}{lllllllllllll}315 & I & E & S & E & E & T & V & T & T & T & D & S\end{array}$

CACTACACAAAAGTGTAACTGAATACCGCAAAAATAATGACAGTAATTAACGGCGTCTACATCAATACGATGACCGCGATCAA CAATGCATACAGCAAGACAATGACAGTGATTAGCATTCTCTACAGCTAGACAATGACAGTGATTAGCATTCTCTACAGCTAGA CAATGACAGTGATTAGCATTCTCTACAGCTAGACAATGACAGTGATTAGCGATGTCTACCGATAGACAACTGTGATTAGCGAT GTCTACAGCTGGGCGACAGTGATTAGCGATGTCTACAGCTGGACGACAGTGATTAGCAATGTCTACCGATAGACAACCATGAC TATATAGTATAATTCTTTGTGTCTACATTTGCTGACTAATAGCAATGGGCAAAAAAAGAAATGTTTTTACAACCTTCGTTTTA CATTGCACATGCATGTTCATTTATCACCCTTTTGATATTAATCATGTTTATATAAAAACAAATCGTTAACTCACCACATTGAT TTTACTTTGTCAAAGTTCACTGCAGTGTATATAGTGCTTTGCATGATATTTTATTGTTTTTATATGCGTTTCTCAATAAATTA TTTACTGTTGAATCATTGAATAAAAAAGCAGAGCTTTAAAAAAAAAAAAAAAAAAAAAAAAAAA

Figure 4 Complete ORF nucleotide and deduced amino acid sequences of the flat oyster OeIRF. ORF contains a DNA binding domain including five conserved tryptophans (underlined in yellow) and polyadenylation signal (AATAAA) (underlined in grey). 
Fig.5

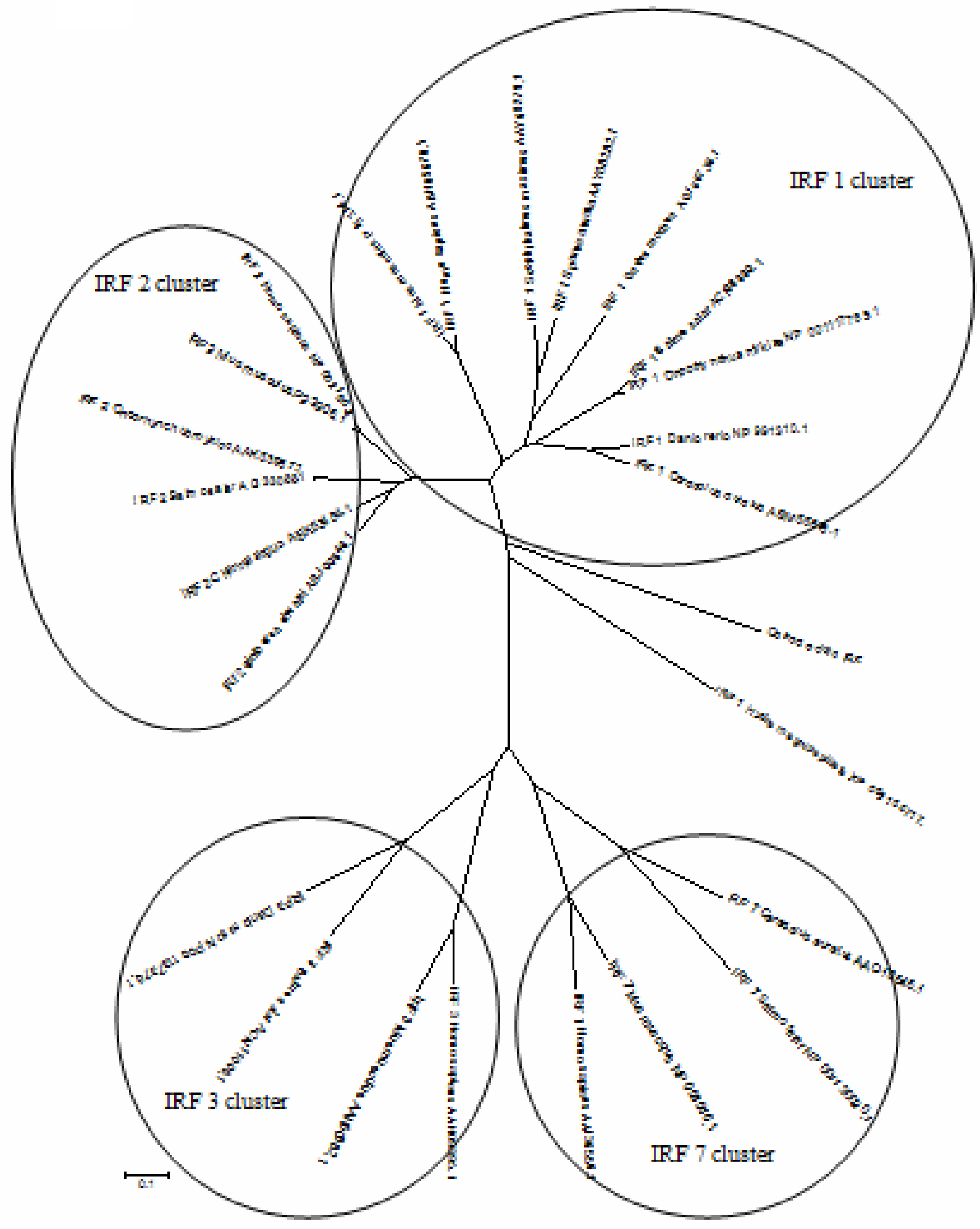

Figure 5 Neighbour-joining tree showing phylogenetic analysis of IRF 1,2,3 and 7 amino acid sequences from various species. The tree is based on 1000 bootstrap replications. The scale for branch length ( 0.1 substitutions/site) is shown below the tree. 
Fig.6

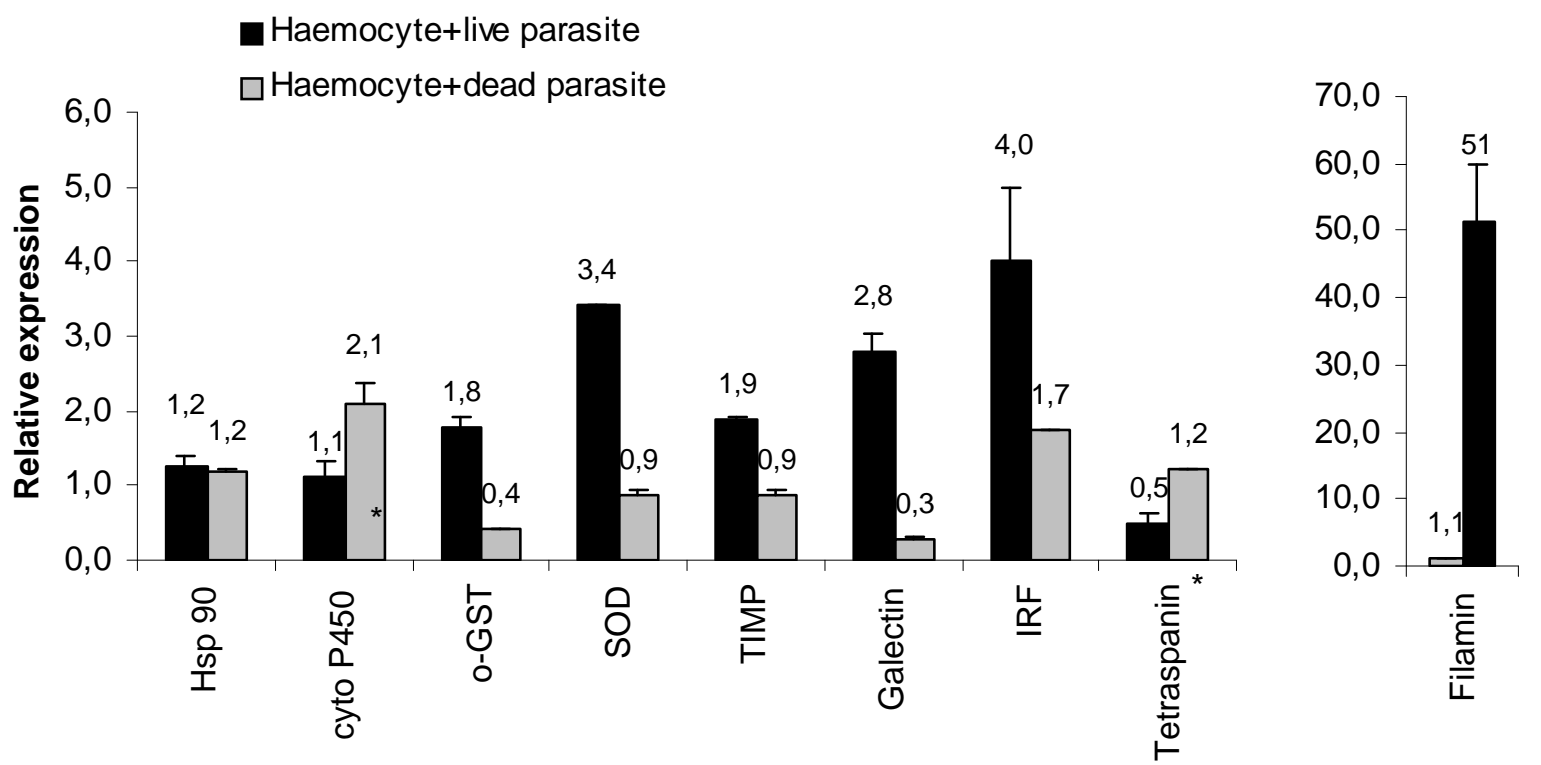

Figure 6 Relative expression by quantitative PCR of selected transcripts from SSH (Hsp 90, cytochrome p450, o-GST, SOD, TIMP, galectin, IRF, tetraspanin and fimanin) libraries. Expression levels were normalized to EF1- $\alpha$ and presented as relative expression to controls (mean $\pm S D, n=2$ ). * indicates significant differences of gene expression compared to controls 